\title{
Identification of Indigenous Knowledge Components for Sustainable Development among the Santhal Community
}

\author{
Laxmiram Gope ${ }^{1}$, Santosh Kumar Behera ${ }^{1, *}$, Rajashri Roy $^{2}$ \\ ${ }^{1}$ Department of Education, Sidho-Kanho-Birsha University, Ranchi Road, P.O. Sainik School, Dist-Purulia, West Bengal, India \\ ${ }^{2}$ Institute of Education, Vinaya Bhavana, Visva Bharati, Santiniketan, West Bengal, India \\ *Corresponding author: santoshbehera.jkc@gmail.com
}

\begin{abstract}
Indigenous knowledge' is community-centric by nature, which reflects community practices and usually possesses deep connection with land, locale and community. Indigenous knowledge is highly tactic and hence it is quite difficult to codify and document Indigenous knowledge. Apart, indigenous knowledge usually disseminates across generation through content and by virtue of observing the various community practices. Indigenous knowledge is highly personalized, and community centric. Therefore, it appears that indigenous knowledge is community specific and traditional by nature. The study aims to know the indigenous practices and their utilization pattern for sustainable development among the Santhal community. To fulfill the objectives, the researchers undertook extensive library work and fields survey. During the survey, it was observed that Santhal community uses various traditional practices. These practices are traditional health care, child rearing practice, agriculture, housing, water preservation, animal nurturing, fishing, forest resource management and so on. This study shows that these practices possess high relevance for achieving sustainability in specific three dimensions viz., social, economic and environmental.
\end{abstract}

Keywords: indigenous knowledge, sustainable development, Santhal community

Cite This Article: Laxmiram Gope, Santosh Kumar Behera, and Rajashri Roy, "Identification of Indigenous Knowledge Components for Sustainable Development among the Santhal Community." American Journal of Educational Research, vol. 5, no. 8 (2017): 887-893. doi: 10.12691/education-5-8-8.

\section{Introduction}

"Indigenous knowledge is an integral part of the culture and history of a local community. We need to learn from local communities to enrich the development process".

James D. Wolfensohn

(President of the World Bank)

The era we leave in, is known as 'Knowledge Era'. In this era of knowledge power is much essential for human resource development, meets the need of Millennium Development Goals (MDG), and achieves it through the utilization of grassroots level knowledge, which is often referred to as community-centered knowledge and is essential for humankind. The Millennium Development Goals are as follows [1]: 1. End poverty in all its forms everywhere. 2. End hunger, achieve food security and improved nutrition and promote sustainable agriculture. 3 . Ensure healthy lives and promote well-being for all at all ages. 4. Ensure inclusive and equitable quality education and promote lifelong learning opportunities for all. 5. Achieve gender equality and empower all women and girls. 6. Ensure availability and sustainable management of water and sanitation for all. 7. Ensure access to affordable, reliable, sustainable and modern energy for all. 8. Promote sustained, inclusive and sustainable economic growth, full and productive employment and decent work for all. 9. Build resilient infrastructure, promote inclusive and sustainable industrialization and foster innovation. 10 . Reduce inequality within and among countries. 11. Make cities and human settlements inclusive, safe, resilient and sustainable. 12. Ensure sustainable consumption and production patterns. 13. Take urgent action to combat climate change and its impacts. 14. Conserve and sustainably use the oceans, seas and marine resources for sustainable development. 15. Protect, restore and promote sustainable use of terrestrial ecosystems, sustainably manage forests, combat desertification, and halt and reverse land degradation and halt biodiversity loss. 16 . Promote peaceful and inclusive societies for sustainable development, provide access to justice for all and build effective, accountable and inclusive institutions at all levels. 17. Strengthen the means of implementation and revitalize the global partnership for sustainable development. To fulfill the MDG [2], we have to reconstruct our knowledge systems and generate new strategies for knowledge creation. Our basic purpose of life is to generate, promote and enhance knowledge among the masses, so that they can utilize it to meet their needs and fulfill the basic requirement of their life. For managing various risks, we codify such kind of community-centered knowledge, which are quite helpful for managing our basic needs without damaging any resource, and preserve our mother earth for various challenges. Therefore, our urgency is to look at in our community, promote their ways of living, and include 
such knowledge, which have cultural value and traditional support. We can found that there are numerous channels of knowledge in community. Usually community members depend over this knowledge. This knowledge is based on different names. Community centered knowledge is also known as indigenous knowledge or situational knowledge or local knowledge or traditional knowledge or poor peoples' knowledge or folk cultural knowledge and survival (strategies) knowledge. The term "Indigenous" means "born in a country, native". It is also derived from the term "Indigena" means "a native". Its derivative sense is Indu ("in, within") + Gen (produce) i.e., "produce from within or native".

Native, Inborn, aboriginal people, those who have common pattern of life in their geographical areas and indigenous knowledge refers to the traditional-knowledge, native people knowledge spiritual knowledge, verbal spiritual knowledge, common knowledge, poor people knowledge, practical knowledge, cultural knowledge as well as situational knowledge which are based on community practices. This community centered knowledge is relevant for various kinds risk management like health care, agriculture, animal husbandry, fishery, education and child rearing practices.

Knowledge comes from epistemology which is one of the main branches of philosophy. Epistemology refers to Science or Study of knowledge". Knowledge is "the fact or condition of knowing something with familiarity gained through experience or association' (Merriam Webster-Dictionary) or awareness, consciousness or familiarity gained by experience or learning (Collins English Dictionary). Justified true beliefs are knowledge.

Nonaka (2006) [3] asserted that knowledge is "a dynamic human process of justifying personal belief towards the truth". He opined that there are two types of knowledge namely, explicit and tacit knowledge. Explicit knowledge can be expressed in formal and systematic language and shared in the form of data, scientific formula, specifications-manuals and others. On the other hand tacit knowledge is 'highly personal and hard to formalize' as it is deeply rooted incaution, procedures, routines, commitments, ideas, value and emotions [4].

\subsection{Definition of Indigenous Knowledge}

- Warren (1991) Indigenous Knowledge (IK) is the local knowledge that is unique to a given culture or society. IK contrasts with the international knowledge system generated by universities, research institutions and private farms. It is the basis for local-level decision making in agriculture, health care, food preparation, education, natural-resource management, and a host of other activities in rural communities $[5]$.

- Flavier (1995) Indigenous Knowledge is the information base for a society, which facilitates communication and decision-making. Indigenous information systems are dynamic, and are continually influenced by internal creativity and experimentation as well as by contact with external systems [6].

- Indigenous knowledge (IK) can be defined as a systematic body of knowledge acquired by local people through the accumulation of experiences, informal experiments and an intimate understanding of the environment in a given culture.

- World Bank (1998) "Indigenous Knowledge is situational knowledge that is unique to every culture of society."[7]

- According to Masango (2010) Indigenous knowledge as the totality of all knowledge and practices established on past experiences and observations that is held and used by people" [8]

- Ascher (2002) opined that 'Indigenous people have had their own ways of looking at and relating to the world, the Universe, and to each other. Their traditional education processes were carefully constructed around observing natural processes, adapting modes of survival, obtaining sustenance from human and animal world, and using natural material to make their tools and implements [9].

Key Concepts of Indigenous Knowledge are as follows:

- Indigenous knowledge is situational knowledge.

- Indigenous Knowledge is unique to every culture or society.

- Profound, detailed and shared knowledge, beliefs and rules with regard to the physical resource, social norms, health, ecosystem, culture, livelihood of the people who interact with environment both in rural and urban settings.

- IK is the basis for local level decision making in:agriculture, health care, food preparation, education, natural resource management and a host of other activities in communities.

- Indigenous Knowledge provides problem solving strategies for communities.

- Communities rather than individual commonly hold indigenous Knowledge.

\subsection{Characteristics of Indigenous Knowledge}

$\square \quad$ IK is locally bound, i.e., indigenous to a specific area.

$\square \quad$ It is culture and context specific.

$\square \quad$ It is non-formal knowledge.

$\square \quad$ It is orally transmitted and generally not documented.

$\square \quad$ It is dynamic and adaptive, not static, changing as the society changes socially, economically, culturally, etc.

$\square \quad$ It is holistic in nature

$\square$ It is closely related to the survival and subsistence of many people worldwide.

$\square$ It belongs to the community-the knowledge is communally owned.

Indigenous knowledge is an emerging area of study that focuses on the ways of knowing, seeing, and thinking that are passed down orally from generation to generation. These way of understanding reflect thousands of years of experimentation and innovation in topics like agriculture, animal husbandry, child rearing practices, education systems, medicine and natural resources management among many other categories (I.P.R).These ways of knowing are particularly important in the era of globalization a time in which indigenous knowledge is accepted as intellectual property and is taking new significance in the search for answers to many of the world's most vexing problems: 
disease, famine, ethical conflicts and poverty. Indigenous knowledge has value, for not only the culture, in which it develops, but also scientists and planners seeking solutions to community problems. Development professionals treasure this local knowledge, finding it extremely useful in solving complex problems of health, agriculture, education and the environment, in developed, developing and under developed countries.

Indigenous knowledge are often utilized in various sector of activities like health care, food preparation, child-rearing practice, education, natural resource management and risks management. Such knowledge is considered as social capital for the poor people. Presently scientists have recognized this knowledge, which has high essence for various kinds of risk-management. These are also relevant for achieving sustainable development. The indigenous knowledge has such potentiality that helps us to tackle the various kinds of hazards regarding environment, economy and social. In holistic perspective, indigenous knowledge is completely separate from the western knowledge system. In modern era if we truly utilize these forms of knowledge in proper (i.e., appropriate) ways and subsequently incorporate in our formal education system, then surely, the objective to achieve national development will be fulfilled and we will be able to reach the global levels, so far man-standard is concerned. Global development will be possible if we truly utilize these forms of local knowledge in development process.

At present juncture of time such study has great impact on knowledge creation, promotion and knowledge implementation in developmental process. Our government can take initiative for incorporate and achieve the development goal through the utilization of indigenous knowledge. Indigenous knowledge has many potentialities. So if we truly incorporate it in our formal education system in all dimensions then it is very sure we will build indigenous education system. Indigenous education system, a pillar for the betterment of our society and leads the society towards progressive and prosperous. If we really identify such knowledge from community, which is much tactic in nature then it is very sure we are able to reconstruct their missing things, which has deep connectivity cultural, traditional, ethical, and practical. Most of the tribal community-suffering inferiority complexes for that region they drink rice beer and they always far from the reality of life .So that their living condition became so low and they are unable to earning their livelihood which is very much essential for survival.

\section{Objective of the Study}

To study the indigenous practices and their utilization pattern for sustainable development among the Santhal community.

\section{Methodology of the Study}

\subsection{Areas of the Study}

The study was conducted in the Bagmundi block of Purulia district of West Bengal, India. This study area is very remote and hilly; therefore there is no proper transparent system and modern facility of life like public health care system, water tank etc. So that people depend on the traditional science (indigenous science) in this area. (Purulia District Map)

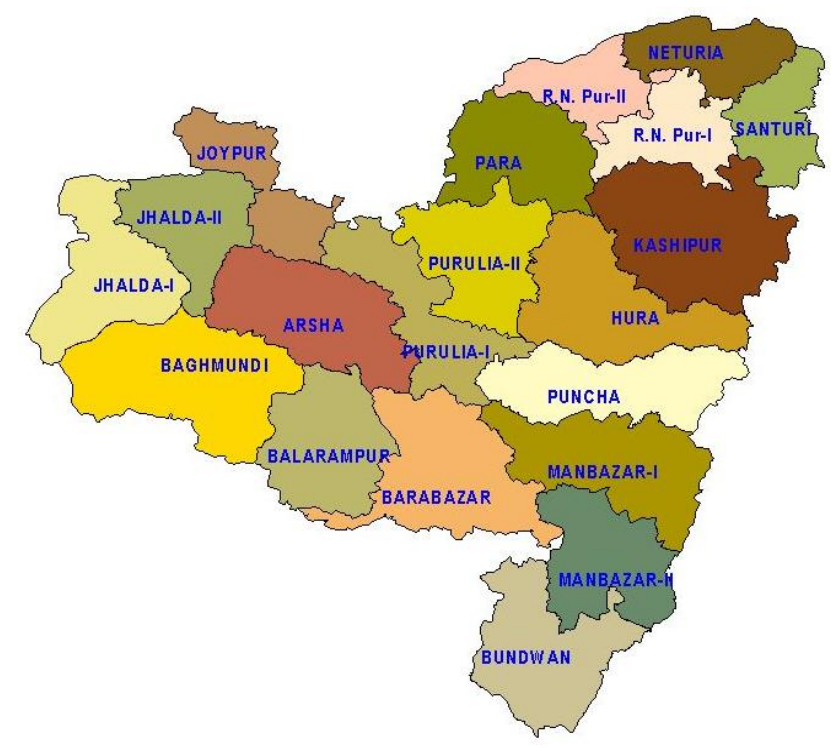

\subsection{Nature of the Study}

Basically this study is naturalistic inquiry because researchers have special insight regarding the Santhal community since their childhood and researchers well acquainted about the Santhal practices and habits though researchers collect data from various sources. However, participatory observational was the primaries based of this study but researchers also prepare an unstructured questionnaire for the expert group. Therefore, the study is based on the primary as well as the secondary sources of data. Later on researchers also conducted extensive library work.

\subsection{Population of the Study}

All the Santhal community members in the Purulia district considered as population of the study.

\subsection{Sample and the Sampling Procedure}

200 Santhal community members selected as a sample by randomly and after that stratified random sampling technique was used for the data collection. The sample was classified on the basis of age group, male, female, literate and illiterate.

\section{Results \& Discussion}

Santhal Community and their Indigenous Practices and Its Utilization for Sustainable Development:

- Santhal and Their Language

According to Universal dictionary by reader digest, the language has been defined as "the aspect of human behaviour that involves the use of vocal sound in meaningful pattern and when they exist, corresponding written symbols to form, express and communicate 
thought and feelings. According to Encyclopedia Britannica, "Language may be defined as an arbitrary system of vocal symbols by means of which human beings as members of social group and participants in culture interact and communicate". Therefore, Santhal language is the core medium for their cultural as well as traditional transformation. In addition to cultural and traditional practices inherent their language and thought, through the language they transformed their custom, knowledge, skills, rituals and all short of behavioral practices. Language is the medium for knowledge transfer. Through the language, we can preserve our old heritages and wisdom. Santali language has own script that is called "ol-chiki", which invent by Pandit Ragunath Murmu. Being of indigenous in nature Santhal language has vast authority of indigenous knowledge.

\section{- Santhal and Their Economic life}

Tribal economy is very simple. A simple thing is difficult to explain. Similarly, the tribal economy perhaps is not easy to analyses [10]. At a glance to understand tribal economy ordinarily mean their material culture involving economic livelihood. Tribal and especially the Santhal understand 'joma-nuya' as economy and consumption and their total economy is centered round these things. In tribal society, economic structure is very simple. Tribal people live in natural surroundings and are close to forest, hill, river, and so on. That is why their economic structure is greatly influenced by forest and natural environments. On the other hand, it creates balanced natural situation or condition in abundance with animals, birds, vegetables and fruits, which enrich their thought and knowledge. There are three main sources of tribal economy. Even today tribal society depends on these economy system- 1) Gathering 2) Hunting 3) Tilling Soil and Cultivation. Tribal community life depends on the forest and they collected resource from forest and continued their lives to sustain. The wealth of forests offered much protection to the tribal community. Other aspects of tribal economy given in the figure below:

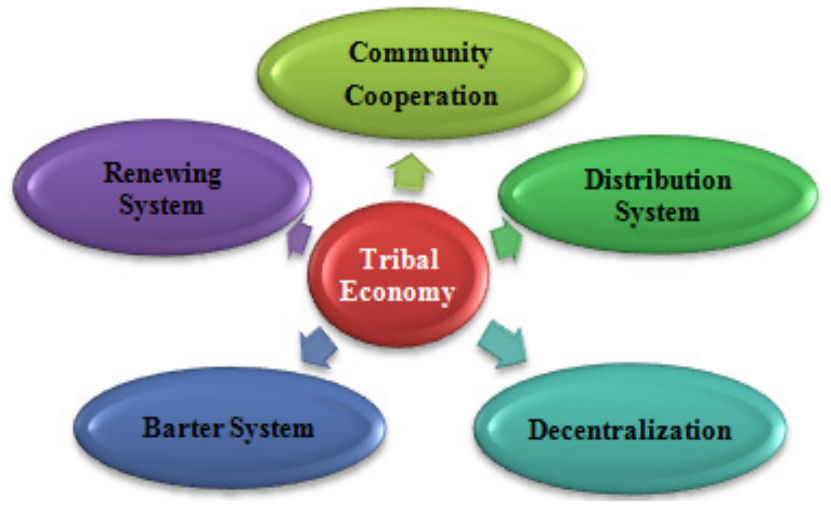

- The Santhal and Their Eternal Culture

The Santhal community has rich cultural heritage. Culture is the integral part of their life. They cultivate and promote different culture throughout the years by various festivals, rituals and traditional practices. Through these cultural practices, they sustain their community life. Therefore, culture and tradition became the integral part of Santhal life, which is the ways or medium for the sustainable development in all aspect of social, economic and environmental. The Santhal community has separate lifestyle, tradition, culture, beliefs and life situation than any other community; through their unique practice, they sustain their community by the help of their own knowledge system and wisdom. The Santhal community has rich heritage of music, song and behavioral pattern. These things are the source of their knowledge system and these are the transformed agency for cultural heritages as well as socio-cultural elements. They have different mode of communications, words used in, speaks of themselves and their rich linguistic pattern and existence. Various ritual and festival practices by the Santhal community--

Soharai Festival--Among the festivals in Santhal community, "Sohorai" is a grand celebration. 'Dansai' is another festival celebrated just before "Sohorai". These two festivals are closer to each other and one follows or proceeds to the other. Their names are uttered almost simultaneously as 'dansai' and 'sohorai. Sohorai follows Dansai. The month on which this festival is celebrated is called 'sahoraibonga' in Santhali. During the 'Soharai' festival, the Santhal community performing various activities among them Santali songs is the one of them. These songs are related to their life struggle and traditional aspect. These songs are the medium of cultural transformation among the new generation and these are the medium for socialization process. In this way, Santhal sustain their old heritage from one generation to the next generation.

Baha Festival--When the nature shifts from one situation to the other, obviously the environmental condition of the surroundings change and such change brings beauty and attraction to nature. 'Baha' time is a kind of transition phase and in this state, the climatic condition is tended and soft. The trees and plants take new form as each of it sprouts new leaves and many trees bear new flowers. Particularly tribal localities situated adjacent to forests, hillocks abound in trees, plants bear flowers, and its scent creates entirely a different atmosphere of joy. 'Sal' and 'Mahua' flowers are the main blossoms found in large number in these localities. 'Baha' means flower and all-round the blooming flowers catch hold of sight. Literary meaning of 'BAHA' is flower. It invites bees and flies to cause pollination for multiplying the number of plants through a process. Santhal community has unique practices as well as unique value of nature worship and their traditional practices, which are deeply, involve with the land, nature, tree and mountain. These practices are separate than the other community. They live in very remote areas and they do not get modern facilities of life but they run their life smoothly by the helps of their indigenous knowledge system, which is grown and nurture by respective community from generation over. Their style of living and interaction with nature is very helpful for sustainable development. As an Indigenous community, Santhal has vast knowledge system and practices, these practices are very much essential for sustainable development. Therefore, we have to concentrate over their indigenous practice.

Maha More-- 'Maha More' is another puja celebration similar to 'baha' festival but it organized with all grandness. This 'Maha More' has more significance since the celebration is not an annual feature like 'BAHA PUJA'. The time of this festival is different in the different zone but the ways of celebration is the same for all zones. In this festival, Santhal communities celebrate with great joy. This festival has great impact on community life because 
it promotes the community living as well as. It promotes the community approaches and common living style. It has special value for achieving sustainable society and the establishment of moral principle among the respective communities. During the field observation researcher found many aspects of cultural as well as traditional practices among the Santhal community, which promote the sustainable development, and achieving the sustainable growth. So this study not only gives weightages on the exploration of cultural dimensions but also emphasis on their traditional medicine, health care, nutrition, resource management as well as environment protection.

\section{- Traditional Medicine}

Santhal community has unique medicinal practices and health care system. They depend on such medicine because; these are the available in local areas and which have economically viable. The Santhal community easily afforded these medicines. So poor Santhal buy these medicines easily and promote their health system from the local medical healer, who treats the people by use of following plants and roots.

\section{- The Santhal and Their Resource Management Techniques}

The Santhal community has unique ways of living and they practice various natural supportive activity or eco-friendly activities. The Santhal people worship to nature, tree, land, river, and mountain as a God. Actually, they are deeply connected with natural reality. During their marriage ceremony groom takes oath in front of tree. Such practice shows that they have faith and devotion on nature and the natural Environment. Consciously or unconsciously, they build their unique knowledge system, which are culturally supportive, economically viable and environmentally sustainable. These activities are very much essential for natural resource management and peace building within the society. There are many practices among the Santhal for managing the natural resource. Such as land management practices, water resource management techniques, house building technique, land fertilizer technique, nature study strategies, tree plantation, soil erosion preventive process and seed protection technique. The Santhal community lives in hilly place and they strongly involve with land because they collect their livelihood from local place through the utilization of local resource. Therefore, they have a unique perception regarding land, nature and water. Therefore, in this perspective the Santhal community practices have many implications for attaining sustainable growth.

Table 1. Traditional Medicine practiced by Santhal Community

\begin{tabular}{|c|c|c|c|c|c|}
\hline $\begin{array}{l}\text { Local/Vernacular } \\
\text { Name }\end{array}$ & English Name & Scientific Name & Part used & Processing & Use and Purpose \\
\hline Halad, haldi & Turmeric & Curcuma longa & Leave & The extracts & $\begin{array}{c}\text { Natural anti-Inflammatory } \\
\text { compound, Digestive efficiency }\end{array}$ \\
\hline Tulsi & Basil & $\begin{array}{l}\text { Ocimum } \\
\text { sanctum }\end{array}$ & $\begin{array}{l}\text { Leave and } \\
\text { seed }\end{array}$ & $\begin{array}{c}\text { The juices of leaves are taken } \\
\text { orally. }\end{array}$ & $\begin{array}{c}\text { Relief from bronchitis, } \\
\text { cough ,common cold and asthma }\end{array}$ \\
\hline $\mathrm{Nim} / \mathrm{Neem}$ & $\begin{array}{l}\text { Margosa or } \\
\text { Neem }\end{array}$ & $\begin{array}{l}\text { Azadirachta } \\
\text { indica }\end{array}$ & $\begin{array}{c}\text { Leave, } \\
\text { Bark }\end{array}$ & $\begin{array}{l}\text { The leaves are taken internally } \\
\text { and used externally. }\end{array}$ & $\begin{array}{c}\text { Skin diseases, fever ailments and } \\
\text { prickly heat etc. }\end{array}$ \\
\hline Golmarich & Black Pepper & Piper nigrum & Fruit & $\begin{array}{l}\text { The fruit in dried and } \\
\text { grounded. The powder fruit } \\
\text { mixed with in honey and taken. }\end{array}$ & $\begin{array}{l}\text { Relief from asthma, cough, and cold } \\
\text { toothache. }\end{array}$ \\
\hline Imli, Amli & Tamarind & $\begin{array}{l}\text { Tamarindus } \\
\quad \text { indica }\end{array}$ & $\begin{array}{l}\text { Flesh, } \\
\text { leaves }\end{array}$ & $\begin{array}{l}\text { The ripe fruit around the seed } \\
\text { are dissolved in water and } \\
\text { taken. }\end{array}$ & $\begin{array}{l}\text { To relief constipation and to destroy } \\
\text { intestinal parasites relief from } \\
\text { asthma, cough and cold toothache. }\end{array}$ \\
\hline Amaltas, Bandarlati & $\begin{array}{l}\text { Sundal, } \\
\text { Golden shower } \\
\text { tree }\end{array}$ & Cassia fistula & $\begin{array}{l}\text { Leaves, } \\
\text { fruit }\end{array}$ & $\begin{array}{l}\text { Leave are grounded and the } \\
\text { powdered leave are taken with } \\
\text { water-pull is also taken. }\end{array}$ & $\begin{array}{l}\text { To get relief from constipation, } \\
\text { scanty micturition, burning } \\
\text { micturition and oedema. }\end{array}$ \\
\hline
\end{tabular}

Table 2. IK Components Utilize / Uses for Sustainable Development:

\begin{tabular}{|c|c|c|c|}
\hline SI. No. & IK Components & Utilizes / Uses For Sustainable Development & $\begin{array}{l}\text { Sustainable Developmental Goals } 2015- \\
2030 \text {. Achieving through the community } \\
\text { centric knowledge or indigenous knowledge }\end{array}$ \\
\hline 1 & $\begin{array}{l}\text { Poverty Reduction } \\
\& \text { Economic Growth }\end{array}$ & $\begin{array}{l}\text { - Use animals for land cultivation and transport. } \\
\text { - Daily money contribution helps to save and lend money. }\end{array}$ & $\begin{array}{l}\text { 1) End poverty in all forms everywhere } \\
\text { 2) End hunger, chive food security and improved } \\
\text { nutrition and promote sustainable agriculture. }\end{array}$ \\
\hline 2 & Health Care & $\begin{array}{l}\text { Fever-Agbo; herbal leaves include pawpaw, guava, mango, etc. } \\
\text { - Stomach ache- ologbo mixture. } \\
\text { - Body pains --Udeibi } \\
\text { - Measles-Udeibi mixed with local herbs } \\
\text { (ebe-orise, erhenre, atanene) } \\
\text { Uses tree as a medicine Kalmag, Sarpaganda, Neem, Arjun, } \\
\text { Baira, Hartike, Chandan and so on. } \\
\text { - Different herbs are collected from the bush, prepared and used } \\
\text { to treat or prevent infant's and adult's disease; incision are made } \\
\text { around the waist, to enhance birth control. }\end{array}$ & $\begin{array}{l}\text { 3) Ensuring healthy lives and promote well- } \\
\text { being for all at ages. }\end{array}$ \\
\hline 3 & Culture & $\begin{array}{l}\text { - Every member of the community considered as an integral part } \\
\text { of the family so their family structure became vital agency for } \\
\text { the cultural transformation. } \\
\text { - Through the use of taboo, telling of folk's tales, methods of } \\
\text { informal training and periodic celebration of traditional festivals, } \\
\text { culture is transferred and preserved. }\end{array}$ & $\begin{array}{l}\text { 4) Ensure inclusive and equitable quality } \\
\text { education and promote life -long learning } \\
\text { opportunities for all. } \\
\text { 5) Achieve gender equality and empower all } \\
\text { women and girls. }\end{array}$ \\
\hline
\end{tabular}




\begin{tabular}{|c|c|c|c|}
\hline Sl. No. & IK Components & Utilizes / Uses For Sustainable Development & $\begin{array}{l}\text { Sustainable Developmental Goals 2015- } \\
\text { 2030. Achieving through the community } \\
\text { centric knowledge or indigenous knowledge }\end{array}$ \\
\hline 4 & Political Stability & $\begin{array}{l}\text { - Corporation is the core value of indigenous group. } \\
\text { - Community meeting at night regarding various issues. }\end{array}$ & $\begin{array}{l}\text { 6) Promote peaceful and inclusive societies for } \\
\text { sustainable development, provide access to } \\
\text { justice for all and build effective, accountable } \\
\text { and inclusive institutions at all levels. } \\
\text { 10) Reduce inequality within and among } \\
\text { countries. } \\
\text { 11) Make cities and human settlements } \\
\text { inclusive, safe, resilient and sustainable. }\end{array}$ \\
\hline 5 & $\begin{array}{l}\text { Reduction of Infant } \\
\text { Mortality }\end{array}$ & $\begin{array}{l}\text { Use indigenous medicine and elder of the family take } \\
\text { responsibility for childrearing .community elders use various } \\
\text { techniques for the nurturing infant. }\end{array}$ & $\begin{array}{l}\text { 3) Ensuring healthy lives and promote well- } \\
\text { being for all at ages. }\end{array}$ \\
\hline 6 & Education & $\begin{array}{l}\text { Learning by conscious as well as unconscious, unique pedagogy, } \\
\text { promote diverse learning and instruct student with example, } \\
\text { avoiding the singling in the class. }\end{array}$ & $\begin{array}{l}\text { 4) Ensure inclusive and equitable quality } \\
\text { education and promote life -long learning } \\
\text { opportunities for all. } \\
\text { 6) Promote peaceful and inclusive societies for } \\
\text { sustainable development, provide access to } \\
\text { justice for all and build effective, accountable } \\
\text { and inclusive institutions at all levels. }\end{array}$ \\
\hline 7 & Population Control & $\begin{array}{l}\text { Indigenous community has unique sensitization towards } \\
\text { population control. Community elders include core value of } \\
\text { humanity among new generation. }\end{array}$ & $\begin{array}{l}\text { 8) promote sustained, inclusive and sustainable } \\
\text { economic growth full and productive } \\
\text { employment and decent work for all. } \\
\text { This goal fulfill through the controlled of } \\
\text { population. }\end{array}$ \\
\hline 8 & Agriculture & $\begin{array}{l}\text { Farming activities are done with the use of IK, which is less } \\
\text { expensive resulting in more crop production and consequently } \\
\text { more supply of food. The alternative, less expensive and readily } \\
\text { accessible means or methods of preventing and treating diseases } \\
\text { have increased chances of survival of both infants and adults. } \\
\text { The sales of farm products and trading activities have made for } \\
\text { income generation with which other necessities of life are } \\
\text { possessed. } \\
\text { Cultivate paddy, wheat, oil etc. }\end{array}$ & $\begin{array}{l}\text { 12) Ensure sustainable consumption and } \\
\text { production pattern. } \\
\text { 13) Protect, restore and promote sustainable use } \\
\text { of terrestrial eco-system, sustainable manage } \\
\text { forests, combat desertification and halt and } \\
\text { reverse land degradation and halt bio diversity } \\
\text { loss. }\end{array}$ \\
\hline 9 & $\begin{array}{l}\text { Resource } \\
\text { Management }\end{array}$ & $\begin{array}{l}\text { - House management, water resource, soil erosion, forest } \\
\text { resource management and family management, control } \\
\text { environmental hazards. } \\
\text { - Shifting cultivation is done to enhance renewal of land. } \\
\text { - Farm pests are controlled. }\end{array}$ & $\begin{array}{l}\text { 6) Ensure available and sustainable management } \\
\text { of water and sanitation for all. } \\
\text { 7) Ensure access to affordable, reliable } \\
\text { sustainable and modern energy for all. } \\
\text { 14) Conserve and sustainable use the oceans, } \\
\text { seas and marine resources for sustainable } \\
\text { development. }\end{array}$ \\
\hline 10 & $\begin{array}{l}\text { Women } \\
\text { Empowerment }\end{array}$ & $\begin{array}{l}\text { Handcraft, domestic product, preparation of indigenous food, } \\
\text { animal nurturing. }\end{array}$ & $\begin{array}{l}\text { 5) Achieve gender equality and empower all } \\
\text { women and girls. } \\
\text { 9) Build resilient infrastructure, promote } \\
\text { inclusive and sustainable industrialization and } \\
\text { foster innovation. }\end{array}$ \\
\hline 11 & $\begin{array}{l}\text { Community specific } \\
\text { Knowledge }\end{array}$ & $\begin{array}{l}\text { Indigenous knowledge is community oriented for example black } \\
\text { smith has technical knowledge about iron. Milkman has special } \\
\text { knowledge about the animal and the milk and its product. }\end{array}$ & $\begin{array}{l}\text { 15) Protect, restore and promote sustainable use } \\
\text { of terrestrial eco-system, sustainable manage } \\
\text { forests, combat desertification and halt and } \\
\text { reverse land degradation and halt bio-diversity } \\
\text { loss. } \\
\text { 14) Conserve and sustainable use the oceans, } \\
\text { seas and marine resources for sustainable } \\
\text { development. }\end{array}$ \\
\hline 12 & Nature Study & $\begin{array}{l}\text { Indigenous community has unique ways of nature study. They } \\
\text { worship nature as a god and they devote themselves for nature } \\
\text { conservation. Soil testing, astrology, seasonal knowledge (Ritu } \\
\text { chakra). }\end{array}$ & $\begin{array}{l}\text { 13) Take urgent action to combat climate change } \\
\text { and its impacts.(In line with the united nations } \\
\text { framework convention on climate change). } \\
\text { 15) Protect, restore and promote sustainable use } \\
\text { of terrestrial eco-system, sustainable manage } \\
\text { forests, combat desertification and halt and } \\
\text { reverse land degradation and halt bio-diversity } \\
\text { loss. }\end{array}$ \\
\hline 13 & Fishing & Manufactured from palm tree for catching fish. & $\begin{array}{l}\text { Utilized local resources/arts for the regional } \\
\text { development. }\end{array}$ \\
\hline 14 & Food & Sun drying is used in preserving majority of the food. & $\begin{array}{l}\text { 12) Ensure sustainable consumption and } \\
\text { production pattern. }\end{array}$ \\
\hline 15 & $\begin{array}{l}\text { Disaster } \\
\text { Management }\end{array}$ & $\begin{array}{l}\text { Many of the indigenous knowledge approaches to environmental } \\
\text { conservation included such technologies and practices as shifting } \\
\text { cultivation, mixed cropping or intercropping, minimum tillage } \\
\text { and agro-forestry, as well as transhumance. These technologies } \\
\text { and practices were commonplace and were used with various } \\
\text { other methods of land use and management to promote higher } \\
\text { yields while at the same time conserving the environment. }\end{array}$ & $\begin{array}{l}\text { 11) Make cities and human settlements } \\
\text { inclusive, safe, resilient and sustainable. } \\
\text { 15) Protect, restore and promote sustainable use } \\
\text { of terrestrial eco-system, sustainable manage } \\
\text { forests, combat desertification and halt and } \\
\text { reverse land degradation and halt bio-diversity } \\
\text { loss. }\end{array}$ \\
\hline
\end{tabular}


Although the Santhal people have been practicing indigenous knowledge components in various spheres of their life since a long time, but sorry to say that till now they are not fully economically sound, achieve food security, ensuring healthy life, quality education and strengthen the means of implementation and revitalize the global partnership. That means the Santhal people have achieved Sustainable Development Goals (SDGs) in some of the cases and till lots to achieve. Hence they are on the way to achieve SDGs through their Indigenous Knowledge practices.

\section{Conclusion}

From the above discussion, we can say the Santhal community indigenous knowledge practice has high essence for sustainable development as well as environmental risk management strategies. The traditional practices of the Santhal community are relevant to sustainable development in various spheres i.e., Social, Economic and Environmental. This study shows that various type of indigenous practices of the Santhal community such as indigenous health care, indigenous culture, festivals, rituals, folklore and traditional laws, song, indigenous resource management etc. have special value in this challenging and changing era. This study also shows that indigenous knowledge has many utilization for controlling environmental hazardous, bio-diversity and bio-piracy. But due to Liberalization, Privatization and Globalization (LPG) indigenous knowledge is decreasing day by day. It is the high time to think about the preservation, promotion and transmission of indigenous knowledge for sustainable development. Lastly we sum up our paper with the African Proverb:

\section{"If Indigenous knowledge is so good,} why is my farm so Poor?"

\section{References}

[1] UN, G. A. (2015). Transforming our world: The 2030 agenda for sustainable development. A/RES/70/1, 21 October.

https://sustainabledevelopment.un.org/post2015/transformingourw orld.

[2] Poverty, E. (2015). Millennium development goals.United Nations. Available online:

http://www.un.org/millenniumgoals/(accessed on 23 August 2011)

[3] Gourlay, S. (2004). A Critical Analysis of Nonaka's Model of Knowledge Dynamics. Electronic Journal of Knowledge Management, 8 .

[4] Olaide, I. A., \& Omolere, O. W. (2012). Management of indigenous knowledge as a catalyst towards improved information accessibility to local communities: a literature review. Chin Librarianship, 35, 87-98.

[5] Warren, D. M. (1991). "The Role of Indigenous Knowledge in Facilitating the Agricultural Extension Process". Paper presented at International Workshop on Agricultural Knowledge Systems and the Role of Extension. Bad Boll, Germany, May 21-24.

[6] Flavier, J.M. (1995). "The regional program for the promotion of indigenous knowledge in Asia", pp. 479-487 in Warren, D.M., L.J. Slikkerveer and D. Brokensha (eds) The cultural dimension of development: Indigenous knowledge systems. London: Intermediate Technology Publications.

[7] The World Bank Annual Report (1998). Parish.

[8] Masango. (2010). A critical control of biodiversity in the context of bio-piracy, South Africa.

[9] Adams, J., Barmby, P., \& Mesoudi, A. (Eds.). (2017). The Nature and Development of Mathematics: Cross Disciplinary Perspectives on Cognition, Learning and Culture. Taylor \& Francis.

[10] Hembram. P. C. (2002). Santali: A Natural Language. New Delhi: Dakshinayan. 